\title{
CASE STUDIES IN ECONOMICS AND ETHICS IN AN EARLY BIOMEDICAL ENGINEERING CLASS
}

\author{
Jerry Collins and Christina Mathieson \\ Department of Biomedical Engineering \\ Vanderbilt University \\ Nashville, TN 37235
}

\begin{abstract}
Biomedical engineering students commit to the major because the profession is growing, interesting, appears financially rewarding, is a bridge to other professions, and because they hope to make a difference in their world. Biomedical Engineering Thermodynamics (BME 102) at Vanderbilt gives opportunity to develop directions for professional and personal purpose through discussions derived from analytical and diagnostic procedures introduced in class material. Examples include:
\end{abstract}

\begin{tabular}{|l|l|}
\hline ANALYTIC/DIAGNOSTIC TOPIC & DISCUSSION TOPIC \\
\hline Material and energy balance in laboratory animals & Use of animals in research \\
\hline Energetics of reactions of DNA and products & Stem cell research and cloning \\
\hline Material exchange in dialysis & Economics/ethics of home dialysis \\
\hline Energetics of mechanical left ventricles and hearts & High costs of medical technology \\
\hline Biomedical device/product, drug development process & Company responsibilities to public \\
\hline
\end{tabular}

Discussions are developed in a learning science format suggested partly by the research hypothesis of our National Science Foundation-funded VaNTH (Vanderbilt-NorthwesternUniversity of Texas/Austin-Harvard/MIT) Engineering Research Center in bioengineering educational technologies. In this model, learners are presented initially with challenges which they think about, then discuss with others. Experts are consulted and conclusions are determined after further discussion. The BME 102 class is divided into small groups representing advocacy positions (Congress, research community, manufacturers, public, etc.) for response to a challenge (i.e., should stem cell research proceed?). Group opinions are formed and stated orally and in writing, and after in-class group presentations, individuals summarize group positions and state their own conclusions in writing. This activity led one former BME 102 student (author CM) to obtain a VaNTH summer research appointment with a leading bioethicist and to pursue career goals conditioned by her summer experience.

\section{INTRODUCTION}

"Then you're at a state of conflict. Because look. Here's how it lays out. If you've got vital insider stuff that the American people for their welfare really need to know and you feel impelled to disclose it and violate your (nondisclosure) agreement (with the company) in doing so, that's

"Proceedings of the 2002 American Society for Engineering Education Annual Conference \& Exposition Copyright $@$ C 2002, American Society for Engineering Education" 
one thing. On the other hand, if you want to honor this agreement, then that's simple. You do so. You say nothing. You do nothing. There's only one guy who can figure that out for you, and that's you, all by yourself."1

The Biomedical Engineering Thermodynamics class (BME 102) at Vanderbilt has the following catalog description:

"Principles of thermodynamics and conservation of mass applied to living systems and biomedical devices. Macroscopic material balances, the first and second laws of thermodynamics, phase and chemical equilibrium, metabolic stoichiometry and energetics." The Spring 2002 syllabus states the course objectives in the following words:

1. To help you apply classical thermodynamics (in particular, the first and second laws) to medical devices, laboratory systems, and living systems.

2. To enable you to write and solve macroscopic material and energy balances on laboratory devices and living systems. Such a knowledge will be useful in specifying and applying medical instrumentation, in analyzing existing and proposed medical devices such as artificial organs, and in the study of quantitative physiology and transport in BME 210, 251, 252, and later courses.

3. To provide a forum for solving problems and addressing relevant bioengineering issues in groups.

Approaches to the thermodynamic and conservation didactic material of the course allows the introduction of complex issues of the personal and professional ethics of the practice of biomedical engineering in the form of challenges, such as the one posed by the quote above from the movie The Insider. ${ }^{1}$ In this example, the responsible conduct of research and responsibilities of a corporation to the general public is discussed while studying the process of biomedical device and drug development. This example is one of several ethical and practice issues that this course addresses. Each ethical issue is introduced in the context of an analytic topic.

\section{PHILOSOPHY OF APPROACH}

"There is no accepted definition of intelligence. Is it thinking speed, reasoning ability, memory, vocabulary, mental arithmetic, mental energy or simply the appetite of somebody for intellectual pursuits that marks them out as intelligent? Clever people can be amazingly dense about some things - general knowledge, cunning, avoiding lamp-posts or whatever. A soccer player with a poor school record may be able to size up in a split second the opportunity and way to make a telling pass. Music, fluency with language and even the ability to understand other people's minds are capacities and talents that frequently do not seem necessarily to go together. Howard Gardner has argued forcefully for a theory of multiple intelligence that recognises each talent as a separate ability. Robert Sternberg has suggested instead that there are essentially three separate kinds of intelligence - analytic, creative and practical. Analytic problems are ones formulated by other people, clearly defined, that come accompanied by all the information required to solve them, have only one right answer, are disembedded from ordinary experience and have no intrinsic interest: a school exam, in short. Practical problems require you to recognise and formulate the problem itself, are poorly defined, lacking in some relevant information, may or may not have a single answer but spring directly out of everyday life. Brazilian street children who have failed badly at mathematics in school are none the less sophisticated at the kind of mathematics they need in their ordinary lives. IQ is a singularly poor predictor of the ability of professional horse-race handicappers. And some Zambian

"Proceedings of the 2002 American Society for Engineering Education Annual Conference \& Exposition Copyright (C) 2002, American Society for Engineering Education” 
children are as good at IQ tests that use wire models as they are bad at ones requiring pencil and paper - English children the reverse."2

College sophomores have reached that point in the educational process largely because they have excelled in an environment of analytic test taking. They have come to expect evaluation in scientific courses of study to be of the analytic type described in the quotation above: clearly defined problems, of a type with which they are familiar. Some of the work they are asked to do in BME 102 is of this sort: homework problems and a fair percentage of material on tests. Other work is of the creative and practical natures: group assignments in which there is no single right answer, but in which they are evaluated on their approaches, on their consideration of multiple factors, and on their abilities to function effectively and creatively as members of a team. In at least three cases, complex processes (respiration, digestion, dialysis) are considered first from simple, then more involved standpoints, so that they may begin to understand that biological and biomedical systems can be approached from many different levels of complexity. At least two major scientific issues of great importance, stem cell research and the cost of biomedical technology development, are discussed from the standpoint of the STAR.Legacy (Software Technology for Action and Reflection, Appendix $1)^{3}$ cycle of learning, which is the learning hypothesis of the VaNTH Engineering Research Center for bioengineering educational technologies. ${ }^{4}$ In all these activities, the goal is the development of analytical, creative, and practical skills, and an enjoyment of the process.

\section{METHODS}

Some topics are approached as group studies, following the model of the STAR.Legacy cycle of learning. First, the class is broken into groups randomly at the beginning of the semester. Next, throughout the semester, the groups are given a specific topic, such as the increasing cost of healthcare or the controversy of stem cell research (see examples below). General background information is also given about the topics. Each group then examines the issue from various given perspectives. The group leader chooses one or two of the given perspectives for further study from the professor, Internet searches, or journal investigations. Once the group has a consensus about how people from their chosen point of view might approach the given issue, the group prepares a three-minute presentation for the class. The group also writes a two-page paper describing its conclusions and how those conclusions were reached from the research of its members and from group discussions.

In addition to the group presentations, the individuals of the group must demonstrate their personal understanding of the ethical topics. They are asked to submit an individual paper $1 \frac{1 / 2}{2}$ pages long. The first page is a summary of the group's consensus. The second part of the paper is a short summary of the individual's thoughts about the subject. No further research is necessary for this section. It should simply demonstrate that the individual understands the ethical issues being discussed, how they apply to science and engineering, and how that issue is controversial when considered from different points of view.

Other ethical and economic issues are presented as case studies, to be approached on an individual basis. In general, these studies are presented either early in the semester, to introduce the students to the concept of case analysis, or late in the semester, when students should have developed abilities to formulate appropriate questions related to the ethics and practice environment involved,

"Proceedings of the 2002 American Society for Engineering Education Annual Conference \& Exposition Copyright (C) 2002, American Society for Engineering Education” 


\section{DISCUSSION}

BME 102 discusses material and energy balances by using dialysis as an example. In this way, students are able to understand a direct biomedical application of the science they are learning. Since these students chose this major for its medical applications, applications of the science make the material more interesting and relevant to them. Similarly, studying dialysis leads to discussions about the increasing cost of healthcare, and the ethics and economics of home dialysis. Students are asked to examine the issue of home dialysis from the perspective of patients, physicians, biomedical engineers, bioethicists, dialysis manufacturing corporations, congress, the Food and Drug Administration, and health insurance companies. (See the case study "Should Our Company Build a Home Dialysis Unit?" in Appendix 2.) Students are also asked to contribute to the list of possible perspectives to extend the list.

Similarly, students discuss stem cell research when learning about DNA and genetic products. (See the case study "Should Stem Cell Research Proceed?" in Appendix 3.) Especially after this past summer's increased controversy about this issue, students were excited to see its relevance in their field of choice. Many students came into BME 102 with the perspective of bioengineer, physician, patient, or scientist. Most students believed that from a medical standpoint, stem cell research should be continued. However, when forced to look at the issue from the angle of a large religious organization or from the view of a large private corporation, students began to understand why compromise was necessary.

One student commented: "As a student who participated in this activity in the spring of 2000, I realized the importance of obtaining an objective point of view in determining possible solutions for these health-related ethical issues. My class examined the issues of stem cell research. We also discussed the increasing cost of health care with a case study of Brian Williams, a young man that received a heart transplant after being on an experimental extracorporeal left ventricular assist device for four months. (See the case study "Was Brian Williams's Treatment Worth the Price?" in Appendix 4.) I remember a wide array of opinions about this subject. At that time, about a third of the class wished to attend medical school, a third wished to continue with graduate school, and the remaining third were planning to enter the biomedical engineering industry. Many of the students planning to go into industry had a better understanding of how the increasing cost of healthcare would affect small and large pharmaceutical companies and insurance corporations. The pre-med students, as I recall, had a fair understanding of the patient and the physician point of view. The patient's family's perspective was also taken into account, as it might differ from the patient's wishes. Finally, the future graduate students seemed to fall between these two groups. Some of these students understood the scenario from the business/corporate point of view. Some of the students looked at the issue from Brian Williams' perspective.

"I don't recall just a single solution coming from the discussions about Brian Williams that spring. However, when discussing ethical issues, there are very often multiple solutions to a single concern. In the case of increasing cost of healthcare, it was mentioned that insurance companies would most likely take care of a majority of the cost as the experimental procedure became more standard. Other students pointed out that, for the present, Brian Williams' procedure was most likely not covered by his insurance company. Most of the treatments for his secondary illnesses and cancers were most likely covered, though. The question of whether people with more money should have access to better healthcare became a concern. From Brian's perspective, it would seem as though that was only fair. If he, or his family, had the funds to support such a procedure, then it would seem unjustified that he not receive it. From his

"Proceedings of the 2002 American Society for Engineering Education Annual Conference \& Exposition Copyright (C) 2002, American Society for Engineering Education” 
family's point of view, though, that money could mean denying another child access to a better college just to add a few more years to Brian's life. In addition, those extra years would most likely not be pain-free, so they could be paying a large sum of money to watch Brian suffer. Although ultimately Brian's story became one of triumph in times of tribulation, the ethical issues that surround his story have yet to be resolved."

As a final exercise in business and personal ethics, the dilemma of the decision of a large, profitable biomedical corporation to create an environmental/ethical trust fund was presented as part of a final examination (see "Ethics or Economics?" in Appendix 5).

\section{CONCLUSION}

The STAR.Legacy cycle of learning was used to illustrate to biomedical engineering students in BME 102 how ethical and economic issues can arise from basic thermodynamic contexts. For example, material balances led to a study of dialysis, which led in turn to the ethics and economics of home dialysis. Stoichiometry led to drug development, which in turn led to responsibilities of pharmaceutical companies to the public. The students from BME 102 can as a result relate to this conversation from The Insider, "'I always thought of myself as a man of science,' said Wygand. 'Then you're in a state of conflict...' responded Bergman."1

\section{APPENDIXES}

\section{APPENDIX 1}

\section{STAR.Legacy: Software Technology for Action and Reflection}

The Legacy software shell allows the creation of guided generative learning environments that use rich macro contexts as anchors for learning. The complexity of these macrocontexts, or challenges, requires the teacher and students to engage in a process of sustained inquiry that can

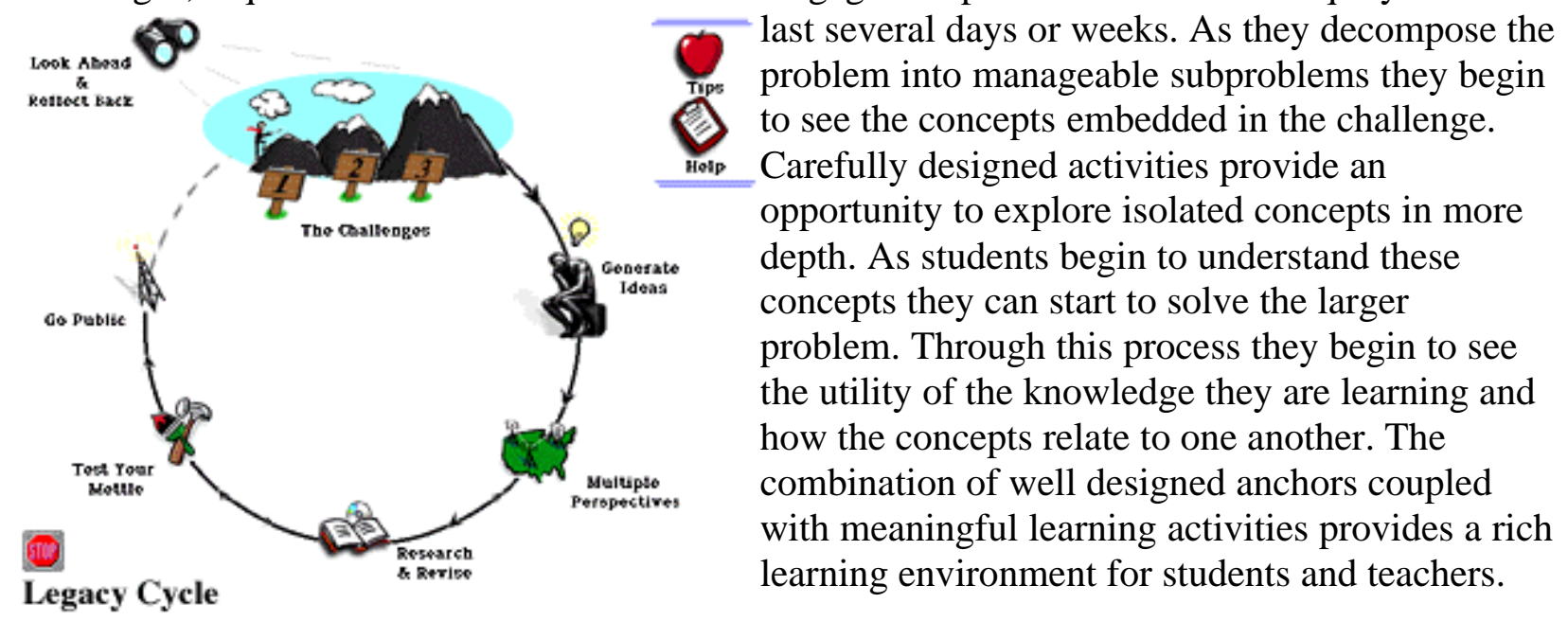

The Legacy software helps students organize and manage learning activities in a meaningful way. This program, called STAR.Legacy (Software Technology for Action and Reflection) helps manage the complexity of macrocontexts by organizing various resources ranging from CDs, the web and other applications, like simulations. The interface uses a visualization of a learning

"Proceedings of the 2002 American Society for Engineering Education Annual Conference \& Exposition Copyright (C) 2002, American Society for Engineering Education” 
cycle as its main organizational scheme. Based on models of problem solving and inquiry, this interface helps instructional designers, instructors, and learners organize their thinking. Each Legacy cycle consists of a series of interrelated challenges, each with its own unique learning cycle. The learning cycle begins with the presentation of a challenge in either video, audio or text format. Then students are asked to reflect on the challenge and to "Generate Ideas". Once they've articulated their thoughts, then they listen to "Multiple Perspectives" from various experts. These experts provide hints about things to think about when solving the problem. However, these hints do not provide a specific solution to the problem. This allows users to compare their naive first impressions with the experts to help them notice their lack of differentiated knowledge. Now they are prepared to engage in a process of "Research and Revise." This stage of the learning cycle organizes resources into meaningful learning activities designed to help them focus on issues related to the initial challenge. Once they feel they've learned enough they can go to "Test your mettle." Here they engage in a set of activities that helps them explore the depth of their knowledge. The goal is to create assessment situations that help them evaluate what they do not know so they can return to the "Research and Revise" section to learn more. Students progress to the "Go Public" stage after proving to themselves that they understand the content well enough to express a solution to the challenge. This cyclical process of active research and reflection on the process provides an excellent opportunity for students to generate their own understanding of the content knowledge.

\section{APPENDIX 2}

\section{CASE STUDY: SHOULD OUR COMPANY BUILD A HOME DIALYSIS UNIT?}

You are an engineer in a firm that is trying to decide whether to design and market a home dialysis unit. This unit will not require the dialysis patient to report to a clinical center for dialysis. Instead, the subject will administer the treatment himself/herself. Your supervisor has asked you to prepare a report of as many factors as you can think of that need to be considered in the decision process. Do the following for your report.

a) Search the Web using google.com or a similar engine to find discussions of dialysis. You are also free to use handouts provided in class, books, or other references.

b) Prepare a three-column table in Word with the following format: In the first column, list the factor to be considered in one or more words. In the second column, discuss the factor in not more than three sentences. In the third column, give the reference for your discussion. Although there is no upper limit to the number of factors you can discuss, you should have at least twenty factors in your list. You will be graded on the quality of your responses.

c) Make a final recommendation based on your report of whether to proceed with design or not.

\footnotetext{
"Proceedings of the 2002 American Society for Engineering Education Annual Conference \& Exposition Copyright (C 2002, American Society for Engineering Education”
} 


\section{APPENDIX 3}

\section{CASE STUDY: SHOULD STEM CELL RESEARCH PROCEED?}

\section{HISTORY}

The Human Genome Project is one of the great scientific triumphs of the twentieth century. In 1953 the double helical structure of DNA was proposed by Francis Crick and James Watson, for which both received the Nobel Prize. More advances followed in rapid succession. In the mid1980s a group of U.S. scientists and political leaders began to realize that mapping the human genome could lead to a new generation of scientific and medical research, with enormous implications for the cure and treatment of disease. The Human Genome Project, projected to be completed by 2005 , was funded at the level of $\$ 3$ billion by the National Institutes of Health in the early 1990s. Other countries joined to work on the project. As work proceeded on the publicly-funded project, a private group developed an alternate approach, and raised huge amounts of private capital to fund their work. New developments in sequence technology accelerated the project, and in June 2000 President Clinton announced from the White House that the public and private efforts had succeeded in mapping the human genome.

Concurrently, great advances in culturing cells for genomic research were being made. The most promising cells for this purpose are stem cells, which are capable of differentiating or changing into cells of virtually any type when placed into culture with cells of that type. Although stem cells have recently been identified in and isolated from some types of organs in adults, it is generally agreed that the best source of human stem cells are blastocysts, an early stage of the human embryo.

\section{ISSUES}

Should stem cell research proceed? This question has been the subject of intense scientific, political, and ethical debate. A great many points of view exist. Some believe that use of embryos for stem cell research is immoral since the embryo is the early human life form and harvesting stem cells from embryos destroys the embryo. Others believe that the use of frozen human embryos left over from in vitro fertilization is permissible since the unused embryos would in all probability eventually be destroyed. Still others believe that the great promise of the alleviation of human suffering legitimizes the use of human embryos for research purposes. There are great differences in opinion about genomic research among the governments of the world. The British Parliament has in principle stated its support for human cloning under certain conditions. The German government tends to oppose embryonic stem cell research in any form. President Bush on August 9, 2001 stated his support for federal funding of research involving embryonic stem cells from existing cell lines, but he opposes the development of new cell lines for that purpose.

\section{ADVOCACY GROUPS}

We will discuss this issue as a class project in BME 102. We will begin our discussion by using our small groups in class to advocate the positions of different interest groups. These groups will include:

1) Bioethicists

2) Large biotechnology and pharmaceutical companies

3) Small biotech and pharmaceutical firms and entrepreneurs

"Proceedings of the 2002 American Society for Engineering Education Annual Conference \& Exposition Copyright @ 2002, American Society for Engineering Education" 
4) Food and Drug Administration and other regulatory agencies

5) Reimbursement groups (Blue Cross/Blue Shield, Medicare and others)

6) Religious groups

7) Environmental impact groups

8) National Institutes of Health

9) Private research foundations

10) Congress

11) Friends and family of people with common and rare disorders

12) Local and state governments and Chambers of Commerce

13) Biotechnology Industry Organization

\section{RESOURCES}

Articles will be posted on the class course management Web site. Teams are encouraged and expected to also search the Web and library for resources.

\section{FORMAT OF STUDY}

Each group will prepare a two-page statement and post it on the class Web site. In class, each group will have 3 minutes to present a summary of its statement. A period of general discussion will follow.

Each individual will write a 1/2-page paper after the discussion. The first page will consist of one-sentence summaries of each group's presentation. The final $1 / 2$ page will be a presentation of the individual's conclusions.

\section{APPENDIX 4}

\section{CASE STUDY: WAS BRIAN WILLIAMS'S TREATMENT WORTH THE PRICE?}

\section{HISTORY}

Brian Williams is a pleasant, articulate young man in his late 20s. He is a graduate student at the University of North Carolina. A decade or so ago, he was diagnosed with a life-threatening heart disorder. A team of physicians and engineers in Pittsburgh decided that Brian's condition was serious enough that he be allowed to receive an extracorporeal left ventricular assist device, a form of artificial heart. This device was highly experimental, and was the result of three decades of research supported by millions of dollars of public and private funding. No one had ever survived with such a device outside acute hospital treatment, but Brian recovered to an ambulatory state, wheeling the heavy cart containing the device around with him and learning how to adjust its settings as necessary. Four months later a suitable donor was found and Brian received an transplanted heart. Since then his heart has continued to function, but the immune system suppression required to keep him from rejecting the heart has led to a series of additional complications: several joint replacements and several cancers, each quite expensive to treat. The total cost of therapy and the underlying research is many millions of dollars.

\section{ISSUES}

Brian Williams himself is not an issue. Brian is an inspiration to everyone. He has persevered in the face of difficulties that would have discouraged many others. 
The development of medical and health care technology is costly. The annual budget of the National Institutes of Health, the leading source of basic medical research in the U.S., is almost $\$ 20$ billion. A fraction of the budgets of the National Science Foundation, the Department of Energy, the Department of Defense, and several other government divisions support applied health care research. Private sources also support health care research. Research budgets of large pharmaceutical companies rival the entire National Science Foundation budget in size. Member companies of AdvaMed, an international biomedical device and product industry organization, spend more than $\$ 11$ billion annually on research and development, against annual revenues of more than $\$ 70$ billion. Member companies of the Biotechnology Industry Organization spend more than $\$ 10$ billion annually on research against annual revenues of about $\$ 20$ billion; much of this expense and revenue is in biologic products related to health care. Health care is our largest national expense, and a significant percentage of that expense is for research and development.

Many argue that our health care costs could be significantly decreased, and the quality and longevity of life increased, if health care moneys could be applied to the promotion of good health care practice: diet, exercise, healthy lifestyle choices. For example, many U.S. citizens are obese; obesity exacerbates diabetes, heart disease, stroke, and many other diseases. The issue, in its most general terms, is: How should our health care dollars and efforts be allocated?

\section{ADVOCACY GROUPS}

We will discuss this issue as a class project in BME 102. We will begin our discussion by using our small groups in class to advocate the positions of different interest groups. These groups will include:

1) Large medical device and pharmaceutical companies

2) Small medical device and product firms and entrepreneurs

3) Food and Drug Administration and other regulatory agencies

4) Reimbursement groups (Blue Cross/Blue Shield, Medicare and others)

5) Advocacy groups for inner-city and rural public health

6) National Institutes of Health

7) Private research foundations

8) Congress

9) Friends and family of people with rare disorders and conditions

10) Local and state governments and Chambers of Commerce

11) AdvaMed

\section{RESOURCES}

Articles will be posted on the class course management Web site. Teams are encouraged and expected to also search the Web and library for resources.

\section{FORMAT OF STUDY}

Each group will prepare a two-page statement and post it on the class Web site. In class, each group will have 3 minutes to present a summary of its statement. A period of general discussion will follow. 
Each individual will write a 1-1/2 page paper after the discussion. The first page will consist of one-sentence summaries of each group's presentation. The final $1 / 2$ page will be a presentation of the individual's conclusions.

\section{APPENDIX 5}

\section{CASE STUDY: ETHICS OR ECONOMICS?}

You are a biomedical engineer who has worked for a large company for several years. As your company has prospered, so has your career. You have risen to a position of responsibility and trust.

One afternoon, the CEO of the company asks you to come into her office and says 'I'm thinking about presenting this statement to our Board of Directors next month." She then places in your hand the following statement.

"As I have presided over this company, I've intentionally placed emphasis on the extraordinary powers of scientific research to lead the way to the development of new product lines that have made this company an international leader in the development of drugs, biomedical products and devices. Our company has led the way to unparalleled improvements in the quality and longevity of human life.

"Now I believe that we should devote those research powers to the equally extraordinary 21 stcentury challenges faced by the global society. Our community, almost alone, has the opportunity to create new options for humankind's quest for the good and full life, while at the same time being responsible stewards for the environment and for future generations.

"There is much to set right. There is a story of a person who was asked, "What do you think of the Bill of Rights?" His answer: "Well, if we owe it, we ought to pay it." So much for history and civics! I was reminded of that story when I heard President Bush, in his first State of the Union address to Congress, say that we should take our "'surplus" national income and "return" it to the people from whom the federal government "took" it.

"I have two problems with that perspective. First, money spent by the federal government is money that we citizens pool to be spent for the common good--defense, education, health, transportation, research etc. That is, we already have it and are spending it for ourselves! Second, we the people have not been paying our bills for a long time. In the 1980s and early 1990s we spent $\$ 4$ trillion more than we took in, and Americans all agree we need to reduce that debt. But that's not all. There are other kinds of bills we haven't been paying. For decades we've been borrowing more than cash from future generations: We have been building up other "nonmarket" debts such as pollution, environmental despoliation, lost water quality, depleted natural resources and depreciated infrastructure.

"It strikes me that in this time of historic affluence we could prudently dedicate a substantial portion of our "surplus" in this country to pay down not only accumulated "market" debt but also our national nonmarket debt. We could start with a nationwide--or even global--cleanup of

"Proceedings of the 2002 American Society for Engineering Education Annual Conference \& Exposition Copyright (C) 2002, American Society for Engineering Education” 
polluted waters, radioactive and toxic wastes, depleted fisheries, and invasive and exotic plants. We could reinvest in the decaying, crumbling physical infrastructure of roads, schools, potable water systems, sewage treatment plants and other public works. We could work to re-establish ourselves as a nation that cares for the well-being of others by raising our participation in assistance to deserving countries to the level that other industrial countries participate. At present our country is near the bottom of the list of givers.

"Finally, wouldn't it be prudent to use part of the "surplus" to continue our national investment in the future by way of increases in research support, not only at the National Institutes of Health but across the board? Research is a very high-yield investment with a 30- to 50-percent rate of return. It is the engine of economic growth. Most of our wealth derives from research supported years ago by others. We have a responsibility to continue such investments to benefit the next generation.

"These matters are of the utmost importance to private as well as public sectors. Our company has ridden the crest of this wave of affluence and has benefited from national and state legislation favorable to our growth. We have not ignored or intentionally abused the environment, but have implicitly benefited from a legislative climate that has allowed us to build production facilities where they would benefit our company most, not necessarily where they would have the least impact on the environment. We have built close to international airports and distribution centers which mimimized those costs to us. We have used our economic leverage to persuade state governments to grant us large tax breaks in exchange for locating our expansions there.

"Accordingly, propose that at the next stockholders' meeting we announce that one percent of our gross revenue this year, which is about $\$ 300$ million based on $\$ 30$ billion in sales last year, be put into a trust fund. The fund will be independently administered but will be devoted to improvement in national and global infrastructure in environment, education and research. Next year I plan to ask for an increase in that amount to two percent."

She then says to you, "I need a one-page response from you of your best thoughts about this presentation. What aspects of it if any do you agree with? Which need to be modified or ignored? Would the company be placed in jeopardy if it adopted this approach? How are the stockholders likely to react?"

She needs your response by the end of this afternoon. ${ }^{5}$

\section{BIBLIOGRAPHY}

1. The Insider, Buena Vista Home Entertainment, 1999.

2. Matt Ridley, Genome: The Autobiography of a Species in 23 Chapters, Perennial, HarperCollins, 1999, p. 80.

3. Brophy, S. P., "STAR:Legacy: Software Technology for Action and Reflection," http://peabody.vanderbilt.edu/ctrs/itc/brophys.legacy1.html.

"Proceedings of the 2002 American Society for Engineering Education Annual Conference \& Exposition Copyright (C) 2002, American Society for Engineering Education” 
4. Schwartz, D. L.; Biswas, G.; Bransford, J. B.; Bhuva, B.; Balac, T.; and Brophy S. Computer Tools That Link Assessment and Instruction: Investigating What Makes Electricity Hard to Learn, In Susan P. Lajoie ed., Computer as Cognitive Tools, Volume Two: No More Walls, 273-307. Mahwah, NJ: Lawrence Erlbaum, 2000.

5. Case study based on: Gibbons, J.H. "Nonmarket Debts and the Tax Cut", American Scientist 89:194, 2001.

\section{BIOGRAPHICAL INFORMATION}

JERRY COLLINS is a member of the biomedical engineering faculty at Vanderbilt University, Nashville, TN. He is industrial liaison for the NSF-sponsored VaNTH Engineering Research Center in bioengineering educational technologies. Dr. Collins's research interests have included microvascular transport and autonomic control. In addition to his membership in ASEE, he is a member of the College of Fellows of the American Institute of Medical and Biological Engineering, a member of the American Physiological Society and the American Association for the Advancement of Science, and is a board member of the Tennessee Biotechnology Association and the Tennessee Biomedical Engineering Consortium. He is a senior member of the Biomedical Engineering Society and has served the BMES as a member of the Board of Directors, as chair and member of the Interface with Industry Committee, and as editor of the BMES Bulletin from 1991-2001.

CHRISTINA MATHIESON is a student in the Department of Biomedical Engineering, Vanderbilt University, Nashville, TN. In summer 2001 she served as an NSF Research Experience for Undergraduates summer intern in bioethics at the Massachusetts Institute of Technology. Ms. Mathieson plans a career in biomedical engineering with an emphasis in research on female reproductive diseases.

This project was supported in part by the Engineering Research Centers Program of the National Science Foundation under award number EEC-9876363. 